УДК: 811.163.41’26

DOI: https://doi.org/10.18485/belic_slv.2018.3.ch11

\author{
Јован Скерлић
}

\title{
КЊИЖЕВНИ ЈЕЗИК И СТИЛ
}

Једна од највиднијих и најважнијих одлика општега напретка у српској књижевности јесте усавршавање књижевнога језика и стила. Стара филолошка школа сасвим се изгубила са својим ненаучним и преживелим схватањима: да је српски књижевни језик довршио своје развијање, и да је језик Вука Караџића и Ђуре Даничића дефинитиван књижевни језик од кога се, као од неке светиње, не сме одступати. Данас је опште примљено схватање да је књижевни језик један жив организам, природан и спонтан производ вазда усавршљивог људског духа, и да се као такав мора развијати, попуњујући се позајмицама сваке врсте, и оживљеним згодним архаизмима и примањем лепо казаних провинцијализама, нарочито прихватањем спонтано посталих неологизама, и да за нове идеје и нова осећања потребни су и нови изрази и нове форме.

У половини XIX века мислило се да је језик којим су Караџић и Даничић превели Библију идеалан српски језик, а писци су писали према тим узорима. Иако је недавно било покушаја да јужно херцеговачко наречје постане опште књижевно наречје српско, иако је та идеја потпуно победила код Хрвата, у српској књижевности остало је, углавном, источно наречје, говор Београда, Шумадије и старе Војводине. Не само да је источно наречје сачувало свој ранији положај, но зато што њиме говори највећи и најкултурнији део српскохрватскога народа, „од Триглава до Солуна", зато што има традицију, зато што је краће, лакше, пословније, енергичније, уједначеније, оно очевидно потискује јужно наречје. Као што је шездесетих година било српских писаца из источних крајева који су почели писати јужним наречјем, тако и сада поједини писци, и српски и хрватски, из југозападних крајева, почињу писати источним наречјем, које је на путу да постане опште и владајуће наречје српске, а вероватно и хрватске књижевности.

У Србији, у Београду, у чисто националној средини, далеко од туђих утицаја, у општој и свестраној употреби коју језик може да да̂ само једна чисто национална држава, ствара се нов књижевни језик, слободан, жив, 
крепак, гибак, живописан, увек у покрету и у стварању. Тај тако названи „београдски стил”, у реакцији против раније филолошке школе и у презирању догматичке граматике и у тежњи за оригиналним изражавањем, каткада иде сувише далеко. Али и поред неизбеживих крајности и злоупотреба, он је једна велика тековина и елеменат напретка у данашњој, српској књижевности. Он, пун снаге и живота, прелази границе Србије и намеће се целој књижевности нашега језика, не само српској но и хрватској. Никада се у српској књижевности није књижевније писало но што је данас, у доба завлађивања „београдског стила”. 